\title{
The Determinants of the Profitability of Micro-Life Insurers in Nigeria
}

\author{
Olajumoke Olaosebikan
}

School of Management, University of Bath, Claverton Down, Bath BA2 7AY, U.K.

E-mail: oo242@bath.ac.uk

Drawing a framework from the financial economics literature and utilising a dynamic panel data design covering 2004-2009, this study examines the profitability of micro-life insurers in Nigeria. The results indicate that the profitability of micro-life insurers is not influenced by factors such as the ownership structure, leverage and size of firms. However, profitability is found to be negatively related to the level of reinsurance suggesting that reinsurance in the micro-life insurance sector of the Nigerian market may be highly priced to reflect the increased risk associated with insuring the lives of low income groups. The link between profitability and the degree to which micro-life insurers have a diversified range of products suggests that multi-product firms are better able to reduce the cost of risk in-house through "natural diversification" as well as realise benefits from economies of scale and scope. Furthermore, the profitability of micro-life insurers operating in Nigeria is found to be positively influenced by the level of interest rates in the economy. This implies that the investment function and macroeconomic factors could be important in assessing the future financial performance of micro-insurance firms in developing countries. Finally, the results of the study could have potentially important commercial and public policy implications.

The Geneva Papers (2013) 38, 140-159. doi:10.1057/gpp.2012.18

Keywords: micro-life insurance; profitability; Nigeria; Sub-Sahara Africa

\section{Introduction}

This study examines the factors that influence the profitability of micro-life insurance providers in Nigeria - a major developing economy of sub-Sahara Africa. ${ }^{1}$ Microinsurance provides risk protection for low income groups and is part of the growing

${ }^{1}$ Short-term micro-life insurance is relatively easier to actuarially price and risk-manage (e.g. in terms of claims validation) than long-term micro-life insurance products, general micro-insurance (e.g. covering property and liability risks) and micro-health insurance. Term life insurance products commonly protect assets that provide lenders (micro-finance banks and credit unions) with the collateral for granting personal and small business loans (i.e. so-called credit-life micro-insurance). Compared with other microinsurance products, life insurance currently has the largest coverage and rate of take-up in developing countries (Roth et al., 2007). Indeed, protecting the life of the main "bread-winner" is often a high priority issue for individuals, families and village communities in emerging economies such as those of sub-Sahara Africa (Jacobsen, 2009). Therefore, the micro-life insurance sector is deemed to be particularly apt as the focus for this study. The scope of the research covers both "compulsory" shortterm (e.g. credit-backed) micro-life insurance and "voluntary" short-term (e.g. personal protection) micro-life insurance. 
international micro-finance industry that emerged in the 1970s. ${ }^{2,3}$ Approximately, 135 million people worldwide currently hold micro-insurance policies with annual rates of growth in some emerging markets estimated to be up to 10 per cent per annum. ${ }^{4}$ However, this number of micro-insurance policies represents only about $2-3$ per cent of the potential market. ${ }^{5}$

By protecting low income groups from the vulnerability of loss shocks, microinsurance is increasingly being spouted as a formalised risk management solution to world poverty and a key driver of economic growth and entrepreneurial development in low income countries such as those of sub-Sahara Africa. ${ }^{6}$ The potentially large size of the global micro-insurance market plus the growing expectation that micro-insurance could be an effective mechanism for reducing world poverty has generated considerable interest among financial institutions eager to expand their business activities outside the saturated traditional markets in developed countries, and international agencies (e.g. the World Bank) concerned with promoting sustainable development in emerging economies.

Despite its potential economic and political importance, academic research on micro-insurance is still very much at an embryonic stage. ${ }^{7}$ Recent studies ${ }^{8}$ have highlighted the challenges and successes of micro-insurance programmes in less developed countries. However, none of these prior studies have examined empirically those factors that determine the profitability of micro-insurance schemes. This study thus seeks to address this gap in the literature.

The present study is important in at least three main regards. First, empirical evidence linking period profitability to firm-specific factors, such as ownership structure, financial structure, amount of reinsurance, firm size and so on, could inform policyholders and shareholders as to whether a micro-life insurance provider is likely to be able to meet its contractual obligations to them. Such an insight could enable prospective customers and capital suppliers to make better insurance and investment decisions. Second, research on the determinants of the profitability of micro-life insurers could help managers make more accurate reserving and reinsurance decisions that could directly benefit future financial performance. Third, the results of the present study could help insurers, reinsurers and others (e.g. international aid agencies) to better understand the underlying economics of micro-insurance firms operating not only in sub-Sahara Africa but also in other parts of the developing world that have similar social and economic characteristics (e.g. Latin America and the Caribbean). This

2 Churchill (2006, 2007); Roth et al. (2007); Matul et al. (2010).

${ }^{3}$ In this research project, low income groups are defined as households who subsist on incomes of U.S.\$4 or less per day (Swiss Re, 2010, p. 9). Because of their limited private collateral people living in poverty are clearly vulnerable to unanticipated life cycle risks such as death and disability (Churchill, 2007). Micro-life insurance products tend to provide low levels of insurance coverage (roughly $\leqslant$ U.S. $\$ 250$ per policy) for fixed periods (typically $2-5$ years) at low rates of annual premium (approximately $\leqslant$ U.S. $\$ 50$ per annum).

4 Lloyd's of London (2009).

${ }^{5}$ Swiss Re (2010, p. 9).

${ }^{6}$ Churchill et al. (2011).

${ }^{7}$ Akotey et al. (2011); Giesbart et al. (2011).

${ }^{8}$ For example, Cohen and Sebstad (2005); Churchill (2006, 2007). 
142

aspect of the research project could also enable multinational financial institutions and others (e.g. consultants) to make more informed strategic decisions in emerging markets (e.g. with regard to prospective joint ventures and acquisitions).

The remainder of the paper is structured as follows. The next section provides some background information on the micro-insurance sector of the Nigerian market. This is followed by the theoretical framework and hypothesis development. The research data and modelling procedure used are explained in the following section, while the empirical results and conclusions are presented in the last two.

\section{Institutional background}

Swiss $\mathrm{Re}^{9}$ reports that with approximately 600 million persons living on less than U.S.\$4 per day (about 20 per cent of the world's poor) sub-Sahara African countries would benefit greatly from micro-insurance initiatives. Nigeria, an Anglophone country in West Africa with a current population of approximately 155 million people, is the most populous nation in Africa and the eighth mostpopulous country in the world. The population of Nigeria comprises about 200 ethnic groups speaking some 500 indigenous languages and split fairly evenly between Christians and other faiths (located mainly in the urban south) and Muslims (located mainly in the rural north). ${ }^{10}$ Approximately, 90 per cent of Nigeria's economic activity is in the primary sector, particularly agriculture and extractive industries such as mining, and oil and gas production. Nigeria's gross domestic product (GDP) in 2009 was U.S.\$173 billion with an annual GDP growth of about 7 per cent, making it the second largest economy in sub-Saharan Africa after the Republic of South Africa (RSA). ${ }^{10}$ Despite recent economic growth, poverty is still a major problem in Nigeria as approximately 70 per cent of the population live on less than U.S.\$4 per day. However, with a gini coefficient of 0.43 Nigeria has a slightly lower average level of national income disparity than other parts of sub-Sahara Africa (where the average gini index is 0.52). ${ }^{10,11}$

Insurance in Nigeria can be traced back to the colonial era of the $19^{\text {th }}$ century with the growth of commercial activities (e.g. shipping and banking) associated with the expansion of the British Empire. ${ }^{12}$ By 1976 there were about 70 insurance providers in Nigeria consisting of 14 foreign-owned and 56 indigenous companies. However, at this time most insurable risks were underwritten by foreign insurance companies, accounting for about 53 per cent of total gross premiums while indigenous insurers accounted for only about 17 per cent due to their limited underwriting capacity. ${ }^{12}$ Since the late 1970s, new laws and regulations have been introduced by the Nigerian government over the last two decades or so to encourage local ownership of insurance companies. ${ }^{12}$ As a result, today domestic investors hold approximately 60 per cent of

\footnotetext{
${ }^{9}$ Swiss Re (2010, p. 15).

${ }^{10}$ World Bank (2010).

${ }^{11}$ The gini coefficient (index) is a measure of national income disparity. The closer the gini coefficient is to 1 , the greater the income variation between rich and poor.

12 Osoka (1992).
} 
the shareholdings of insurers operating in Nigeria. Government intervention in the local insurance market also led to the growth of solely owned indigenous insurance firms. However, such entities tend to have limited underwriting capacity and low financial performance compared with larger insurance providers. In 2007, Nigeria's National Insurance Commission (NAICOM) sought to rationalise the domestic insurance market by raising capitalisation thresholds thus increasing underwriting capacity and promoting greater product-market competition. By 2009, there were 30 companies operating in the micro-life insurance sector of the Nigerian market (see section "Data").

As Yusuf et al. ${ }^{13}$ point out, the present level of annual premiums as a proportion of per capita GDP (i.e. insurance penetration) in Nigeria is, at 1 per cent, very low compared with some other sub-Sahara Africa countries such as the RSA (which currently has an insurance penetration rate of 16 per cent). Nonetheless, despite the low level of insurance penetration in Nigeria micro-insurance is not a new concept. For example, in the 1980s Nigerian insurers began to promote micro-insurance-type products known as "industrial insurance" (or esusu) to low income groups. However, such products were often unsustainable due to difficulties associated with premium collection, lack of reliable systems of claims management, low rates of renewal, and a generally held public mistrust of the value of insurance. ${ }^{14}$ While there are no dedicated micro-insurance companies presently operating in Nigeria, local conventional insurance providers do provide micro-insurance products. The products are distributed either directly to the individual customers/cooperative groups via agents/ brokers or promoted through insurance subsidiaries of micro-finance institutions (MFIs), particularly banks.

Nigeria is considered to be a good environment within which to focus the present research project for two main reasons. First, the demand and supply of microinsurance in Nigeria is growing in line with broader micro-finance development initiatives and domestic economic growth and development. ${ }^{13}$ Cohen and Sebstad ${ }^{15}$ add that in sub-Sahara Africa, consumer demand for key asset (prime-earner) protection (life and health) insurance is moving away from local community-based self-insurance (risk retention) to external risk pooling (risk transfer). This arises as individuals seek to improve their economic situation and small businesses focus on diverting resources from unproductive self-insurance arrangements to more productive income-generating activities. Therefore, Nigeria offers a potentially interesting domain within which to examine the profitability of micro-life insurance providers but at the same time provide insights that can be generalised to other developing countries in sub-Sahara Africa and elsewhere. Second, the market for micro-life insurance in Nigeria comprises a mix of different organisations of varying size and type of shareholdings. This institutional feature could be potentially useful for testing empirically the effect of different firm-specific characteristics in influencing the profitability of micro-life insurance firms.

\footnotetext{
${ }^{13}$ Yusuf et al. (2009).

14 Omar (2007).

${ }^{15}$ Cohen and Sebstad (2005).
} 


\section{Theoretical framework and hypotheses development}

This section briefly outlines the key theoretical concepts derived from the financial economics literature that underpin the present study. Hypotheses drawn from this literature are also put forward in this section of the paper to help direct empirical testing.

\section{Theoretical framework}

\section{Information asymmetry}

The notion of asymmetric information and its impact on influencing market microstructure is closely related to agency theory and the economic incentives conflicts that can arise between different contracting constituents (e.g. shareholders, policyholders and managers) due to the increased separation of ownership from control as organisations grow in size. ${ }^{16}$ Rothschild and Stiglitz ${ }^{17}$ demonstrated that adverse selectionthat is, the ability of insured agents (policyholders) to withhold private information on their risk profile ex ante in order to secure ex post economic advantages from insurance providers (e.g. through higher than anticipated claims) - is all-pervasive in insurance transactions. Moral hazard, on the other hand, arises where the outcome of the insurance contract can be influenced by the (unobserved) actions of the insured after an insurance policy has been taken out. ${ }^{18}$

\section{Agency costs}

Agency costs are the direct and indirect costs incurred in ensuring that agents (i.e. managers) and other contracting constituents (e.g. policyholders) act in the best economic interests of principals (i.e. owners). ${ }^{16}$ Arrow ${ }^{18}$ reports that because of agency and other costs associated with information asymmetries, insurance markets are imperfect necessitating prospective solutions, such as contractual covenants and organisational structures, to reduce such business costs.

Insurance markets comprise different ownership structures with the two most common forms being the stock and mutual forms of organisation. ${ }^{19}$ However, in many jurisdictions (including Nigeria) variations in the type of ownership structure can also exist within the stock form of organisation. For example, equity can be held by a few large (majority) investors, disparate individual investors and/or by managerial-owners. $\mathrm{He}$ and Sommer ${ }^{20}$ further contend that owner-manager-policyholder (agency) conflicts are most likely to be acute when widely held ownership rights predominate.

Mayers and Smith $^{21}$ further classify the ownership structure of common stock insurance companies into four main groups, namely: "association-owned stock firms", "mutual-owned stock firms", "closely-held stock firms", and "widely-held stock

\footnotetext{
16 Jensen and Meckling (1976).

${ }^{17}$ Rothschild and Stiglitz (1976).

18 Arrow (1963).

${ }^{19}$ Mayers and Smith $(1981,1982,1988)$.

${ }^{20} \mathrm{He}$ and Sommer (2010).

${ }^{21}$ Mayers and Smith (1994).
} 
firms". They argue that "mutual-owned" stock firms are similar to conventional mutual insurance companies because the shareholders are also the policyholders of the association or the parent mutual. In large (particularly publicly listed) closely-held stock firms, there is often a merger of the manager and shareholder functions which helps to substantially reduce owner-manager conflicts but which might come at a cost for policyholders (e.g. as a result of excessive risk-taking). Closely-held stock firms can be further classified into "closely-held stock firms owned by managers" or "closelyheld stock firms owned by other investors" depending on the amount of equity held by insiders (managers). However, for widely held stock insurance firms there is usually a clear separation of shareholder-manager-policyholder functions. He and Sommer ${ }^{20}$ contend that if left unchecked by contractual control and incentive alignment mechanisms, such a structure could increase agency problems (costs) in the firm.

\section{Hypotheses}

\section{Ownership structure}

Prior studies $^{22}$ suggest that local mutual/cooperative-type organisations are particularly apt in the context of micro-insurance in developing countries. This is because mutual forms of organisation provide close ex ante control over the entry policyholders to the insurance pool (e.g. through the application of strict underwriting criteria) and introduce ex post controls to minimise aberrant behaviour by policyholders and managers (e.g. in the form of contractual mechanisms). Therefore, mutual forms of insurance organisation can be especially effective in mitigating adverse selection and moral hazard problems, and reducing the agency cost of ex post monitoring and contractual enforcement. However, mutual/cooperative organisational forms do not exist in the Nigerian micro-insurance sector. Consequently, in the present study the effect of a continuum of shareholding-types in reducing information asymmetry and agency problems is the focus of analysis. The ownership structures examined include: closely-held private insurers, widely held (often publicly listed) investor-owned insurance companies and private insurers closely held by ownermanagers. Insurers that are closely held tend to be privately owned subsidiaries of banks (i.e. bancassurance organisations). Mayers and $\mathrm{Smith}^{21}$ argue that for closelyheld stock firms, tighter monitoring and control of managerial activities by owners reduces information asymmetry and agency costs thus increasing the market value of the firm. However, for widely held stock insurers less stringent monitoring and control of managers by shareholders leads to higher agency and information asymmetry costs compared with closely owned entities. Therefore:

H1a: Other things being equal, closely-held stock micro-life insurers are likely to be more profitable than widely held stock micro-life insurers.

However, Mester's ${ }^{23}$ expense preference hypothesis implies a different perspective on the profitability-effect of ownership structure by arguing that agency costs can be

\footnotetext{
${ }^{22}$ For example, Ligon et al. (2002); Paal and Wiseman (2011).

${ }^{23}$ Mester (1989).
} 
relatively more acute in closely-held stock (privately owned) firms rather than widely held (publicly traded) firms. This is because without the "disciplining effect" of the market for corporate control, the managers of closely-held stock insurers are likely to increase agency costs (e.g. through excessive perquisite consumption and on-the-job shirking) especially in situations where the level of inside (managerial) ownership is low. As a result, an alternative hypothesis is:

H1b: Other things being equal, widely held stock micro-life insurers are likely to be more profitable than closely-held stock micro-life insurers.

Mayers and $\mathrm{Smith}^{21}$ further argue that the closer the merger of the owner-manager functions, the lower the agency costs of monitoring and control. Owner-managers are also motivated to take decisions that increase period profitability and increase the value of their ownership stake in the firm. For the two classes of closely-held stock insurers, the agency costs of monitoring and control are expected to be relatively higher in micro-insurers with closely-held stock held by large investors (banks) than in micro-insurers that are closely held by management. As a consequence:

H1c: Other things being equal, micro-life insurers with closely-held stock owned by management are likely to be more profitable than micro-life insurers that have closely-held stock owned by large banks.

On the other hand, micro-insurers with closely-held stock owned by banks could be more profitable than micro-insurers closely-held stock by management because bancassurers could have inherent economic advantages compared with managementowned entities. For example, banks tend to have extensive distribution networks that enable their micro-insurance subsidiaries to develop a large and diversified customerbase. ${ }^{24}$ The information asymmetry problems (i.e. moral hazard and adverse selection) could also be substantively reduced for micro-insurers that are closely held by banks due to their ability to accurately access the creditworthiness of micro-customers from records held by the parent banking corporation. Therefore:

H1d: Other things being equal, micro-life insurers with closely-held stock owned by banks are likely to be more profitable than micro-life insurers with closely-held stock owned by management.

\section{Leverage}

Adams and Buckle ${ }^{25}$ define financial leverage in the context of insurance markets as the ability of an insurer to effectively fulfill their contractual commitments to policyholders and other fixed claimants without having to increase profits on underwriting and investment activities. However, high leverage can reduce period profitability as insurers are likely to retain free cash flows (reserves) in order to minimise the risks of financial distress and bankruptcy. To the extent that many insurance companies (particularly life insurers) invest a substantial proportion of their

${ }^{24}$ Angove and Tande (2011).
${ }^{25}$ Adams and Buckle (2003). 
premiums in assets (such as bonds) that match the size and duration of their policy liabilities, profitability could further be adversely affected by increases in market rates of interest (see section "Control variables"). Increased leverage also induces agency problems, such as the underinvestment incentive, that can reduce annual profitability due to the associated increase in the costs of monitoring and control. ${ }^{26}$ Consequently:

H2a: Other things being equal, highly leveraged micro-life insurers are likely to be more profitable than lowly leveraged micro-life insurers.

On the other hand, an alternative view is predicted by Jensen's ${ }^{27}$ free cash flow hypothesis. This hypothesis holds that high leverage levels can actually be valueenhancing for firms as the obligation to meet the repayment schedules under debt covenants disciplines managers to act in ways consistent with shareholders' wealth maximisation objectives. This encourages managers to generate future cash flows thus increasing period profitability and the traded value of the firm. Insurance company managers can also realise "tax shield benefits" from increasing leverage thus enhancing annual reported profits. ${ }^{28}$ Additionally, Purnanandam ${ }^{29}$ contends that in the absence of legislative restrictions and regulatory controls (which are both likely in microinsurance markets), high leverage can actually induce excessively risky behaviour thus increasing "upside abnormal" profits. Therefore, an alternative hypothesis is:

H2b: Other things being equal, highly leveraged micro-life insurers are likely to be more profitable than lowly leveraged micro-life insurers.

\section{Reinsurance}

In their micro-insurance study from Malawi, Hochrainer et al. ${ }^{30}$ highlight the importance of sufficient risk capital in ensuring the solvency of micro-insurers and emphasise that this is one of the most important challenges facing micro-insurers in sub-Sahara Africa. Insurers can manage their capital position and improve balance sheet strength (thus mitigating insolvency risk and the costs of regulatory intervention) not only by increasing equity but also by transferring part of their liabilities for

\footnotetext{
${ }^{26}$ The underinvestment incentive is a classical agency cost of debt problem. It arises in highly levered states when an unexpectedly severe loss to collateralised assets motivates owners of the firm to exercise their "default put option" under limited liability rules and so avoid reinstating lost or impaired productive assets. Owners of firms are motivated to undertake this action because the future economic benefits of post-loss asset reinstatement are perceived to accrue largely to fixed claimants (e.g. debtholders) rather than themselves as residual risk-bearers. In the context of insurance markets the underinvestment problem can be mitigated by the purchase of reinsurance. For example, Mayers and Smith (1990) argue that reinsurance protects the fixed claims of policyholders by ensuring that after unexpectedly severe losses, the proceeds from reinsurance treaties can be used to meet claims and support reserves. The facility to utilise reinsurance reduces the risks of financial distress and/or bankruptcy for insurance firms, and improves their profitability by lowering their market costs of capital (see section "Reinsurance").

27 Jensen (1986).

${ }^{28}$ For example, see Adams et al. (2008).

${ }^{29}$ Purnanandam (2008).

${ }^{30}$ Hochrainer et al. (2009).
} 
assumed risks to third-party reinsurance companies. In other words, reinsurance is a contingent form of financing for insurance companies which enables them to efficiently readjust their equity, optimise their market cost of capital and maintain future underwriting capacity after a severe loss event. ${ }^{31}$ As noted earlier, ${ }^{26}$ the purchase of reinsurance can also contribute to sustainable profitability by mitigating agency problems such as the underinvestment problem. Reinsurance can also lower expected taxes by reducing the variability of future earnings and so contribute to the traded value of insurance firms. ${ }^{32}$ Reinsurance has also been identified as one of the vital links in the sustainability of micro-insurance schemes in times of environmental disasters and economic shocks. ${ }^{33}$ As a result:

H3a: Other things being equal, highly reinsured micro-life insurers are likely to be more profitable than micro-life insurers with low levels of reinsurance.

On the other hand, Doherty and Garven ${ }^{34}$ report that the purchase of reinsurance can be costly for primary insurance writers (e.g. in terms of brokerage fees and ceded premiums) and thereby reduces profitability and the market value of insurance firms. This reasoning implies that:

H3b: Other things being equal, lowly reinsured micro-life insurers are likely to be more profitable than micro-life insurers with high levels of reinsurance.

\section{Control variables}

The financial performance of micro-life insurers can also be affected by other firmspecific factors such as size, product-mix and age as well as macroeconomic factors such as the annual rates of interest and inflation in the domestic economy. The motivation for including the control variables used in the present study is outlined below.

Firm size: Adams and Buckle ${ }^{25}$ suggest that large insurers are likely to have better financial performance than small insurers because they can realise scale economies through increasing output and economising on the unit costs of technology and product development. Large insurers can also more efficiently diversify assumed risks and so reduce the unit cost of risk in the management of their underwriting portfolios. However, Adams and Buckle ${ }^{25}$ also point out that the profitability of large insurers could be adversely affected by the enhanced information asymmetries and agency costs that often arise when organisations get bigger. Therefore, the predicted effect of firm size on the profitability of micro-life insurers is not clear from the literature.

Product-mix: Abdul Kader et al. ${ }^{35}$ report that the operational efficiency, and hence profitability, of insurance firms could be affected by their product-mix as multi-product

\footnotetext{
${ }^{31}$ Mayers and Smith (1990).

32 Adams et al. (2008).

33 Dror and Armstrong (2006).

34 Doherty and Garven (1995).

35 Abdul Kader et al. (2010).
} 
insurers are likely to benefit not only from economies of scale but also from economies of scope in the use of shared inputs (e.g. labour, technology and so on). Mathewson ${ }^{36}$ also acknowledges that in multi-product insurance firms managers can spread assumed risks across different lines of insurance by imposing different underwriting criteria in order to realise economic gains in particular market segments while concomitantly keeping overall underwriting risk within acceptable bounds. Therefore, it is expected that, all else equal, multi-line micro-life insurers will be more profitable than micro-life insurers with a narrow product-range.

Length of time in the market: The length of time an insurance provider has been operating in the micro-life segment of the market could influence period profits. For example, established operatives are expected to have better local knowledge and a more dedicated salesforce than new entrants to the market. Therefore, other things being equal, the length of time in the local micro-life insurance market is likely to be positively related to profitability.

Interest rates: Doherty and Garven ${ }^{34}$ suggest that profit margins reflect the average price of traded insurance policies and that in competitive markets insurance prices follow, and are inversely related to, the movement of average annual interest rates in the economy (which in Nigeria are currently at roughly 8 per cent per annum according to the World Bank $^{10}$ ). This reasoning implies an inverse relation between profitability and interest rates. On the other hand, high interest rates can improve yields on investments such as cash deposits and bonds. ${ }^{37}$ This suggests that there will be a positive linkage between the profitability of micro-insurance schemes and the level of interest rates in the economy. ${ }^{38}$ Therefore, the predicted effect of interest rates on the level of profitability of micro-life insurers is ambiguous.

Inflation: Cargill and Troxell ${ }^{39}$ propose that price inflation particularly affects the profitability of life insurance products because it alters consumption patterns. Therefore, micro-life insurance may not adequately serve the interests of individuals and families in developing countries that experience high annual rates of inflation (which in Nigeria is currently running at about 11 per cent per annum according to the World Bank ${ }^{10}$ ).

\section{Research design}

Data

The main data sources are the annual financial statements of insurance firms compiled by the Nigerian Insurers Association (NIA) and the NAICOM. The data covers the six-year period from 2004 to 2009. Where information on micro-life insurance business could not be identified from published sources, data was then obtained directly from internal company sources. In the estimation of the allocation of

\footnotetext{
${ }^{36}$ Mathewson (1983).

${ }^{37}$ Smith (1989).

${ }^{38}$ Cummins (1991).

${ }^{39}$ Cargill and Troxell (1979).
} 
expenses, it was assumed that the cost of writing the micro-insurance business is proportional to its gross premium income. As noted earlier (section "Hypotheses"), all the life insurance firms offering micro-life insurance products for which data could be obtained are stock companies. The sample started with 53 micro-life insurance suppliers in 2004 but this number was reduced to 30 firms by 2009 as a result of local market consolidation. By the end of the sample period, the data set comprised nine privately owned insurance firms (20 firms in 2004), seven firms privately owned by banks (eight firms in 2004), and 14 publicly listed stock insurance firms (25 firms in 2004). The data set was further "cleaned" by eliminating firms with less than two years of financial data thus leaving an unbalanced panel data set of 149 firm-years. To test the research hypotheses ( $\mathrm{H} 1 \mathrm{a}$ to $\mathrm{H} 1 \mathrm{~d})$, micro-life insurance firms are further categorised into three sub-categories of stock ownership classes based on the separation of ownership from control. Privately owned micro-life insurance firms are labelled as closely held stock firms owned by management because the ownership of the company rests internally within the firm. The second group of micro-life insurers are classed as closely-held stock firms privately owned by banks, while the third group of firms are labelled as widely-held stock firms as share ownership is held by a disparate group of public investors.

\section{Modelling procedure}

The econometric model employed to examine the profitability of Nigerian micro-life insurers is Generalised Methods of Moments (GMM) dynamic panel data estimation. ${ }^{40}$ GMM estimation takes account of dynamic adjustments in micro-life insurers' annual profitability over time and so represents a potentially more robust estimation technique that is less prone to estimation bias than other pooled cross-sectional/times series regression procedures such as pooled ordinary least square (OLS). ${ }^{41}$ The GMM specification used in the present study is defined as:

$$
P R O F_{i t}=\left(P_{R O F} F_{i t-1},\left\{V A R I A B L E S_{i t}\right\},\left\{C O N T R O L S_{i t}\right\}\right)+\eta_{i}+v_{t}+\varepsilon_{i t} .
$$

In the above equation, $P R O F_{i t}$ represents net profitability for firm $i$ in year $t$ as defined in Table 1 . The variable $P R O F_{i t-1}$ is the lagged measure of annual profitability. The symbols $n_{i}$ and $v_{t}$ represent observable and unobservable firm-specific and timespecific effects respectively, while $\varepsilon_{i t}$ is an error tem which is assumed to be serially uncorrelated and normally distributed with a mean $=0$ and variance $=1$. The label $\left\{V A R I A B L E S_{i t}\right\}$ is a vector of the key explanatory variables and $\left\{C O N T R O L S_{i t}\right\}$ is a vector of the control variables again as defined in Table 1.

In the GMM estimation, firm-effects (e.g. managerial talent) are assumed to vary across micro-life insurer but remain constant for each micro-life insurer, and timeeffects (e.g. changes in the macroeconomic environment) are assumed to be the same for all micro-life insurers in a given year but will vary across years. Hence, the model

\footnotetext{
40 Arellano and Bond (1991); Blundell and Bond (1998); Bond (2002).

${ }^{41}$ Baltagi (2004).
} 
Table 1 Definition and description of variables

\begin{tabular}{|c|c|}
\hline Variables & Definition and description \\
\hline \multicolumn{2}{|l|}{ Dependent variable: } \\
\hline 1. Profitability $(P R O F)$ & $\begin{array}{l}\text { This variable is defined as: } N P=\left[P-(C-L)-\left(E+C_{o}\right)+\mathrm{I}+\left(V_{0}-V_{t}\right)\right] \div T A \text {, where } \\
N P=\text { net profit; } P=\text { premiums earned (net of reinsurance); } C=\text { claims } \\
\text { (net of reinsurance recoverable); } L=\text { lapses; } E=\text { expenses; } C_{o}=\text { commissions; } \\
I=\text { investment income (net of fees); } V_{0}-V_{t} \text { are reserves at the start and end } \\
\text { of the year; and } T A=\text { total invested assets }\end{array}$ \\
\hline \multicolumn{2}{|l|}{ Independent variables: } \\
\hline $\begin{array}{l}\text { 2. Ownership structure } \\
(\text { OSTRUC })\end{array}$ & $\begin{array}{l}\text { This is represented by dummy variables for each stock ownership class considered, } \\
\text { namely; }\end{array}$ \\
\hline & $\begin{aligned} D_{p} & =1 \text { for closely-held stock micro-life insurer, and } \\
& =0 \text { for widely-held stock micro-life insurer. }\end{aligned}$ \\
\hline & $\begin{array}{l}D_{p m}=1 \text { for closely-held stock by management, } \\
\quad=0 \text { if otherwise. }\end{array}$ \\
\hline & $\begin{array}{l}D_{p b}=1 \text { for closely-held stock by banks, and } \\
\quad=0 \text { if otherwise. }\end{array}$ \\
\hline 3. Leverage $(L E V)$ & $\begin{array}{l}\text { This variable is defined as [net (of reinsurance) life insurance liabilities } \\
+ \text { other liabilities] } \div \text { capital/surplus. }\end{array}$ \\
\hline $\begin{array}{l}\text { 4. Reinsurance } \\
(\text { REINS) }\end{array}$ & $\begin{array}{l}\text { This is measured as annual reinsurance premiums ceded } \div \text { gross annual premiums } \\
\text { written. }\end{array}$ \\
\hline \multicolumn{2}{|l|}{ Control variables: } \\
\hline 5. Firm size $(S I Z E)$ & $\begin{array}{l}\text { Firm size is measured as the natural logarithm of annual total assets. This approach } \\
\text { alleviates the possible effects of extreme values confounding the empirical results. }\end{array}$ \\
\hline 6. Product-mix $(M I X)$ & $\begin{array}{l}\text { Product-mix is measured by a Herfindahl concentration index that is computed using } \\
\text { four major classes of products sold by life insurers in Nigeria, namely: individual } \\
\text { micro-credit/protection micro-life insurance and group microcredit/protection micro- } \\
\text { life insurance. The Herfindahl index is computed for each company as: } M I X=\sum_{j=1}^{4} S_{j}^{2} \\
\text { where } S_{j} \text { is the amount of annual premium income written in the } j^{\text {th }} \text { line of insurance } \\
\text { divided by the total value of annual premium income for all four lines. The closer the } \\
\text { Herfindahl index is to one, the more concentrated the product function } \\
\text { of micro-life insurance firms. }\end{array}$ \\
\hline $\begin{array}{l}\text { 7. Length of time in } \\
\text { the market }(A G E)\end{array}$ & $\begin{array}{l}\text { This is defined as the number of years a micro-life insurer has been operating } \\
\text { in Nigeria. }\end{array}$ \\
\hline 8. Interest rate $(I N T)$ & This variable is measured as the average annual commercial bank interest rate. \\
\hline 9. Inflation $(I N F L)$ & This variable is measured as the average annual change in the consumer price index. \\
\hline
\end{tabular}

specification used is designed to capture the effects of unobservable firm heterogeneity and macroeconomic forces outside management's direct control. The GMM model also contains a lagged dependent variable $\left(P R O F_{i t-1}\right)$ recognising that a micro-life insurer's annual profitability may not adjust instantaneously to changes in the explanatory variables, and that there may be endogeneity (i.e. reverse causation) due to some regressors being correlated with past and current values of the error term $\varepsilon_{i t}$. To control for possible endogeneity an instrumental variables approach is adopted. ${ }^{42}$ The Sargan test of over-identifying restrictions is then used to test for first-order and second-order serial correlation in the first difference residuals. Following Blundell and 
152

Bond $^{43}$ and Bond, ${ }^{42}$ the GMM system (GMM-SYS) estimator is applied to improve the efficiency of the coefficient estimates. In the event, all diagnostic tests carried out confirmed that GMM-SYS estimator is efficient.

\section{Empirical results}

This section of the paper reports and discusses the empirical results.

\section{Descriptive statistics and correlation coefficients}

The descriptive statistics and correlation coefficients of the dependent, independent and control variables are presented in Table 2 .

Panel A of Table 2 reveals that the average annual profitability of Nigerian micro-life insurers over the sample period (2004-2009) is about 6 per cent; however, the high standard deviation (std. dev. $=0.31$ ) suggests extreme variability in the level of profitability among the firms in the data set. The results for the ownership structure dummy variables $-D_{p}, D_{p m}$ and $D_{p b}$-indicate that closely held (private) stock firms on average account for 44 per cent of the micro-life insurance market in Nigeria. This percentage of the market is split roughly equally between closely-held stock firms owned by management $\left(D_{p m}\right.$, mean $\left.=0.22\right)$ and closely-held stock firms owned by banks $\left(D_{p b}\right.$, mean $\left.=0.24\right)$. The use of reinsurance is also relatively low (mean $=0.10$, std. dev. $=0.14$ ) among all the sample firms examined with some micro-life insurers ( $n=35$ firm/years) having no reinsurance arrangements at all over the period of analysis (2004-2009). Ostensibly, this observation suggests that most micro-life insurers in Nigeria tend to self-retain rather than reinsure the risk of their micro-insurance products due to the relatively low premiums received from these products and/or the high market cost of reinsurance.

Panel A of Table 2 reveals generally high levels of leverage ( $L E V)$ for the microlife insurers in the data set (mean=1.62) but again with considerable variation among firms (std. dev. $=2.37$ ). Overall, the descriptive statistics indicate that on average micro-life insurers' liabilities tend to exceed the level of capital/surplus raising the possibility that micro-life insurance products may be "cross-subsidised" by conventional business. Also, the results for firm size (SIZE) reported in panel A of Table 2 indicate that by international standards, micro-life insurance suppliers in Nigeria appear to be small firms with the largest firm having a total asset value of just over U.S.\$28 million. The Herfindhal concentration index $(M I X)$ (with mean $=0.65$, std. dev. $=0.14$ ) indicates that micro-life insurers in Nigeria tend to be diversified entities. Additionally, the descriptive statistics results reflect a large variation in the length of time $(A G E)$ that the firms in the data set have been operating in the domestic micro-insurance market (median $=20$ years, std. dev. $=14.17$ years). This large variation is not unexpected given that the micro-insurance market in Nigeria largely emerged in the 1980s and has gradually increased as opportunities have grown over the last decade or so. Finally, the statistics reported in panel A of Table 2

\footnotetext{
${ }^{43}$ Blundell and Bond (1998).
} 
Olajumoke Olaosebikan

Determinants of the Profitability of Micro-life Insurers

Table 2 Descriptive statistics and correlation coefficients for micro-life insurers in Nigeria (2004-2009)

\begin{tabular}{lcccccc}
\hline & Mean & Median & St. dev & Min & Max & No. of obs. \\
\hline $\begin{array}{l}\text { Panel A: Descriptive statistics } \\
\text { PROF }\end{array}$ & 0.06 & 0.03 & 0.31 & -1.27 & 1.33 & 135 \\
OSTRUC: & & & & & & \\
$\quad D_{p}$ & 0.44 & 0.00 & 0.49 & 0.00 & 1.00 & 148 \\
$D_{p m}$ & 0.22 & 0.00 & 0.41 & 0.00 & 1.00 & 148 \\
$D_{p b}$ & 0.24 & 0.00 & 0.43 & 0.00 & 1.00 & 148 \\
REINS & 0.10 & 0.04 & 0.14 & 0.00 & 0.79 & 142 \\
LEV & 1.62 & 0.76 & 2.37 & -4.37 & 14.24 & 136 \\
SIZE & 12.05 & 12.24 & 1.63 & 9.04 & 15.33 & 136 \\
MIX & 0.65 & 0.63 & 0.14 & 0.21 & 1.00 & 119 \\
AGE & 24.33 & 20.00 & 14.17 & 1.00 & 52.00 & 148 \\
$I N T$ & 17.52 & 17.95 & 1.18 & 15.48 & 19.18 & 148 \\
$I N F L$ & 11.71 & 11.60 & 4.14 & 5.50 & 17.92 & 148 \\
\hline
\end{tabular}

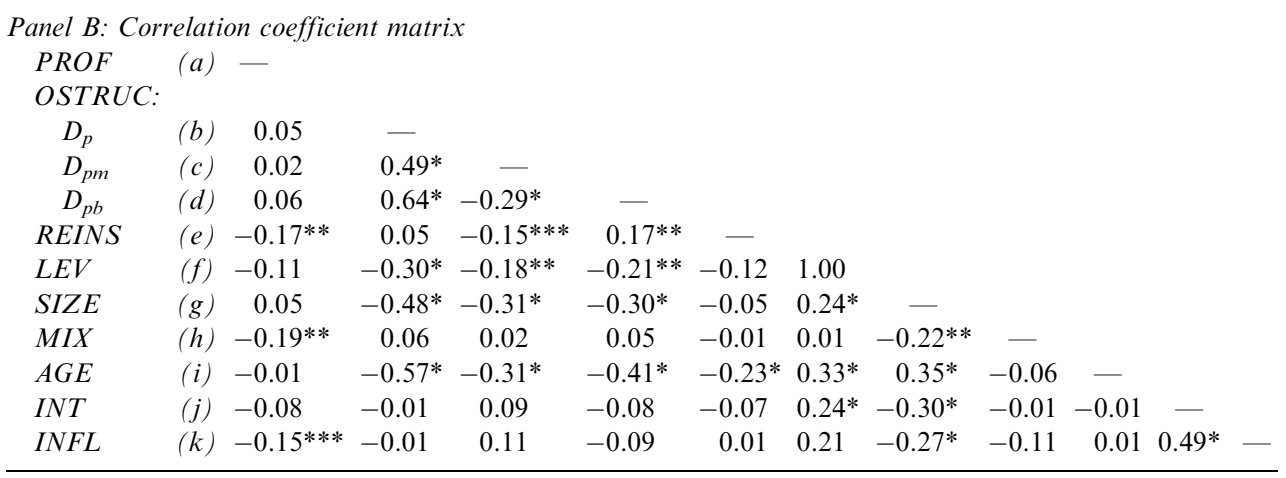

Note: $P R O F$ is net profitability $(N P)$ which is measured as $N P=\left[P-(C-L)-\left(E+C_{o}\right)+\mathrm{I}+\left(V_{0}-V_{t}\right)\right] \div T A$, where $N P=$ net profit; $P=$ premiums earned (net of reinsurance); $C=$ claims (net of reinsurance recoverable); $L=$ lapses; $E=$ expenses; $C_{o}=$ commissions; $I=$ investment income (net of fees); $V_{0}-V_{t}$ are reserves at the start and end of the year; and $T A=$ total invested assets. OSTRUC is the ownership structure of a micro-life insurer which is represented using three dummy variables; $D_{p}=1$ for closely-held stock micro-life insurer, $0=$ widely-held stock micro-life insurer. $D_{p m}=1$ for closely-held stock owned by management, $0=$ otherwise and $D_{p b}=1$ if closely-held stock owned by banks, $0=$ otherwise. $R E I N S=$ level of reinsurance which is measured as annual reinsurance premiums ceded $\div$ gross annual premiums written. $L E V=$ leverage which is defined as [net (of reinsurance) life insurance liabilities + other liabilities] $\div$ capital/surplus. $S I Z E=$ firm size, measured as the natural logarithm of annual total assets. $M I X=$ product mix, measured using the Herfindhal concentration index. $A G E=$ length of time a micro-life insurer has been operating in the market.

$I N T=$ average annual commercial bank interest rate and $I N F=$ inflation which is measured as the average annual change in the consumer price index.

Unlogged values of firm size (in Nigerian Naira/U.S. dollars) are: mean = NGN171 million (U.S.\$ 1.06 million); median =NGN206 million (U.S.\$1.2 million); min. =NGN8.43 million (U.S.\$0.05 million); and $\max .=$ NGN4.54 billion (U.S.\$28.1 million).

Correlations coefficients involving metric-measured variables are computed using Pearson Product Moment Correlation Analysis, while correlation coefficients involving non-metric-measured (e.g., dummy) variables are computed using Spearman Rank Correlation Analysis. Superscripts *, ** and ***=statistically significant at 1, 5 and 10 per cent level (two-tailed) respectively. 
show that the rates of interest (INT) and inflation (INFL) were generally high (mean annual interest rates=approximately 18 per cent; mean annual inflation=roughly 12 per cent) and that these rates again fluctuated widely over the sample period. These statistics thus point to unstable macroeconomic conditions in Nigeria between 2004 and 2009, which could have had an adverse impact on the overall demand for, and supply of, micro-life insurance products.

Table 2, panel B presents the correlation coefficients between all the variables used in the study. The results indicate a positive but statistically insignificant association between profitability $(P R O F)$ and the ownership structure $\left(\right.$ OSTRUC) variables $-D_{p}$, $D_{p m}$, and $D_{p b}$. Nevertheless, the signs of the derived correlation coefficients are consistent with the view that agency costs of monitoring and control tend to be higher in widely-held stock (public) firms than in closely-held stock (private) firms. ${ }^{20} \mathrm{In}$ addition, the correlation coefficients between $O S T R U C, L E V, S I Z E$ and $A G E$ are negative and statistically significant ( $p \leqslant 0.01$, two-tailed), which indicates that closelyheld (private) stock micro-life insurers have lower levels of leverage, are smaller in size, and tend to be relatively new entrants to the micro-life insurance sector of the Nigerian market than widely-held (public) stock firms.

The correlation analysis reported in Table 2, panel B also indicates a negative and statistically significant ( $p \leqslant 0.05$, two-tailed) association between PROF and the level of reinsurance (REINS) suggesting that, consistent with the descriptive statistics, micro-life insurers with low levels of reinsurance have higher profitability than their counterparts that have taken out relatively more reinsurance. This observation implies that the high cost of reinsurance might have a negative effect on the profitability of micro-life insurers as predicted by H3b. Interestingly, microlife insurers with closely-held stock owned by management $\left(D_{p m}\right)$ are associated with lower amounts of reinsurance than their counterparts that are closely held by banks. This suggests that the insurance subsidiaries of banks are better placed than owner-manager-owned micro-life insurance firms to secure reinsurance possibly because they have a more prominent market profile and/or lower perceived risk of loss.

The Herfindhal concentration index $(M I X)$ also indicates a negative and statistically significant correlation with PROF ( $p \leqslant 0.05$, two-tailed) implying that multi-line product micro-life insurers are more profitable than micro-insurers with a more limited range of product. This finding is also consistent with previous studies. ${ }^{44}$ Finally, a negative and statistically significant ( $p \leqslant 0.10$, two-tailed) correlation is noted between INFL and PROF suggesting that high inflation in the local economy could adversely affect the market demand for micro-life insurance products and hence the profitability of micro-life insurance firms. ${ }^{39}$

\section{Multivariate analysis}

The multivariate results derived from the GMM estimation are presented in Table 3. Two sets of analysis were carried out with panel A using the OSTRUC dummy

\footnotetext{
${ }^{44}$ For example, Mathewson (1983); Abdul Kader et al. (2010).
} 
Table 3 Dynamic panel data estimation - one step GMM-SYS results: Micro-life insurers in Nigeria (2004-2009)

Panel A:

Dependent variable:

PROF

\begin{tabular}{|c|c|c|c|c|c|}
\hline & Coefficient & $t$-stat & & Coefficient & $t$-stat \\
\hline$P R O F_{t-1}$ & -0.03 & -0.02 & & -0.15 & -1.08 \\
\hline \multirow{2}{*}{ OSTRUC: $D_{p}$} & 0.12 & 0.47 & OSTRUC: $D_{p m}$ & 0.15 & 0.71 \\
\hline & & & $D_{p b}$ & -0.14 & -0.36 \\
\hline REINS & $-0.64 * *$ & -1.75 & & $-0.54 * * *$ & -1.29 \\
\hline$L E V$ & -0.03 & -0.58 & & -0.01 & -0.09 \\
\hline$S I Z E$ & -0.04 & -0.57 & & -0.06 & -0.97 \\
\hline$A G E$ & -0.001 & 0.08 & & 0.002 & -0.33 \\
\hline$M I X$ & $-0.69 * *$ & -2.10 & & $-0.61 * *$ & -1.76 \\
\hline$I N T$ & $0.06^{* * *}$ & 1.39 & & $0.06^{* * *}$ & 1.44 \\
\hline$I N F L$ & 0.01 & 0.52 & & 0.02 & 0.70 \\
\hline Time effects & Yes & & & Yes & \\
\hline Hansen & 0.961 & & & 0.995 & \\
\hline Diff- Hansen & 0.875 & & & 0.734 & \\
\hline AR (1) & 0.041 & & & 0.076 & \\
\hline AR (2) & 0.434 & & & 0.333 & \\
\hline No. of instruction & 37 & & & 41 & \\
\hline
\end{tabular}

Note: Panel A reports the results of the one-step GMM-SYS estimator using the OSTRUC dummy variable $\left(D_{p}\right)$ to examine the profitability of closely-held (private) stock vs. widely-held (public) stock micro-life insurers while Panel B gives the results using the OSTRUC variables $\left(D_{p m}\right.$ and $\left.D_{p b}\right)$ to examine the profitability of micro-insurers with closely-held stock owned by "management" vs. closely-held stock owned by "banks".

Asymptotic robust standard errors are computed for the $t$-statistics as reported in both panels A and B. The exogenous variables, lagged at levels $(3,4)$ for the first difference and level equations, are used as instruments. The values reported for the Hansen test are $p$-values for the null hypothesis of the validity of the instruments. The Diff-Hansen also reports the $p$-values for the validity of the additional moment restrictions required by the GMM-SYS estimator. AR (1) and AR (2) report the $p$-values for the first-order and secondorder autocorrelation disturbances in the first difference equation.

$P R O F$ is net profitability $(N P)$ which is measured as $N P=\left[P-(C-L)-\left(E+C_{o}\right)+\mathrm{I}+\left(V_{0}-V_{t}\right)\right] \div T A$, where $N P=$ net profit; $P=$ premiums earned (net of reinsurance); $C=$ claims (net of reinsurance recoverable);

$L=$ lapses; $E=$ expenses; $C_{o}=$ commissions; $I=$ investment income (net of fees); $V_{0}-V_{t}$ are reserves at the start and end of the year; and $T A=$ total invested assets. OSTRUC is the ownership structure of the microlife insurer which is represented using three dummy variables; $D_{p}=1$ for closely-held stock micro-life insurer, $0=$ widely-held stock micro-life insurer. $D_{p m}=1$ for closely-held stock owned by management, $0=$ otherwise and $D_{p b}=1$ if closely-held stock owned by banks, $0=$ otherwise. $R E I N S=$ level of reinsurance which is measured as annual reinsurance premiums ceded $\div$ gross annual premiums written. $L E V=$ leverage which is defined as [net (of reinsurance) life insurance liabilities + other liabilities] $\div$ capital/surplus. $S I Z E=$ firm size, measured as the natural logarithm of annual total assets. $M I X=$ product mix, measured using the Herfindhal concentration index. $A G E=$ length of time a micro-life insurer has been operating in the market.

$I N T=$ average annual commercial bank interest rate and $I N F=$ inflation which is measured as the average annual change in the consumer price index.

Superscripts $*, * *$ and $* * *=$ statistically significant at the 1,5 and 10 per cent level respectively. One-tailed tests are used when the hypothesised direction is implied; otherwise two-tailed tests are used. 
variable $\left(D_{p}\right)$ to examine the profitability of closely-held (private) stock vs. widely-held (public) stock micro-life insurers, and panel B using the OSTRUC variables $\left(D_{p m}\right.$ and $\left.D_{p b}\right)$ to examine the profitability of micro-insurers with closely-held stock owned by management compared with closely-held stock firms owned by banks.

The multivariate results reported in Table 3 (panels A and B) indicate that current period profitability $(P R O F)$ is unrelated to past financial performance as the estimated coefficients of the lagged profitability variable $\left(P R O F_{t-1}\right)$ are statistically insignificant. Additionally, the sign of the correlation coefficient estimates for PROF and the OSTRUC variables $-D_{p}, D_{p m}$, and $D_{p b}$-are positive but statistically insignificant suggesting that the type of shareholdings of Nigerian micro-life insurers does not influence their profitability. However, the coefficient estimates for REINS reported in Table 3 (panels A and B) are negative and statistically significant (at $p \leqslant 0.05$ and $p \leqslant 0.10$, one-tailed). This observation is consistent with $\mathrm{H} 3 \mathrm{~b}$ and Doherty and Garven's ${ }^{34}$ study which suggests that the transaction costs of reinsurance could have a deleterious impact on insurers' profitability and their traded value. In the context of micro-insurance markets, this finding could also indicate that reinsurance prices reflect the increased risks associated with insuring (the inherently risky) lives of low income groups. However, the coefficient estimates for $L E V$ and SIZE are not statistically significant suggesting that the amount of debt in the capital structure and the firm size does not have any direct impact on the profitability of micro-life insurers in Nigeria. On the other hand, Table 3 (panels A and B) indicates that the coefficient estimates for $M I X$ have an inverse and statistically significant relation with $P R O F(p \leqslant 0.05$, onetailed). This finding is consistent with the empirical evidence reported in previous studies $^{35}$ and suggests that multi-product micro-life insurers are likely to be more profitable than their counterparts with a narrow product-range as a result of their ability to more efficiently diversify assumed risks and/or benefit from economies of scale and scope. Finally, the interest rate variable (INT) is positive and statistically significant ( $p \leqslant 0.10$, two-tailed). This finding indicates that high rates of interest in the economy are likely to improve the period profitability of micro-life insurers-for example, by improving yields on investments such as cash deposits and bonds. ${ }^{37}$ This observation further implies that the profitability of micro-insurers could be influenced more by period investment returns rather than profits realised on the underwriting function. ${ }^{38}$

\section{Conclusions}

This study uses a dynamic panel data design (GMM) covering the period 2004-2009 to examine the profitability of micro-life insurers operating in Nigeria. Contrary to what was hypothesised, the profitability of micro-life insurers is not related to factors such as the ownership structure, leverage and size of firms. However, profitability is found to be negatively related to the level of reinsurance. This suggests that reinsurance in the micro-life insurance sector of the Nigerian market may be highly priced to reflect the increased risk associated with insuring the lives of low income groups. The link between profitability and the degree to which micro-life insurers have a diversified range of products suggests that 
compared with their counterparts with a narrow range of products, multi-product insurers are better able to reduce the cost of risk in-house and realise benefits from economies of scale and scope. Furthermore, the profitability of micro-life insurers operating in Nigeria is found to be positively influenced by the level of interest rates in the economy. This implies that the investment function and macroeconomic factors are important in assessing the future financial performance of micro-insurance firms in developing countries.

The results of this study could have important commercial and public policy implications. First, the inverse relation between profitability and the amount of reinsurance could suggest that reinsurers may need to "moderate and modify" their reinsurance prices in micro-insurance markets - for example, by reducing reinsurance rates where the micro-insurer is "naturally diversified". Additionally, reinsurers could, for example, offer micro-insurers "conditional fixed-period cut price" reinsurance cover until such time that sufficient volumes of business have been generated to enable adequate underwriting data (e.g. experience rating) systems to be developed. Second, in highlighting that reinsurance has potential costs as well as risk transfer benefits this study could be important to local insurance industry regulators and others (e.g. credit ratings agencies) in their solvency monitoring and performance assessment of micro-insurers. Third, the influence of high interest rates in promoting the overall profitability of micro-life insurance firms emphasises the importance of both the investment function and wider macroeconomic considerations in the analysis of the performance of micro-insurance schemes. Again this insight could be important to international insurers and reinsurers in their analysis of strategic investment opportunities in emerging markets.

Finally, it is acknowledged that interpretation of the results of this study may need to be tempered by recognition of the inherent limitations of the research design usedsuch as the small sample size and limited data publicly available. Nonetheless, it is considered that despite these potential limitations, the data used does provide some interesting results that can be examined further in future research.

\section{Acknowledgements}

The assistance of Elena Veprauskaite and the Nigerian insurance industry during the course of this study is very much appreciated. The financial support provided by the Reinsurance Group of America (RGA) doctoral scholarship is also gratefully acknowledged. Finally, the usual disclaimer applies.

\section{References}

Abdul Kader, H., Adams, M.B. and Hardwick, P. (2010) 'The cost efficiency of Takaful insurance companies', The Geneva Papers on Risk and Insurance - Issues and Practice 35(1): 161-181.

Adams, M.B and Buckle, M. (2003) 'The determinants of corporate financial performance in the Bermuda insurance market', Applied Financial Economics 13(2): 133-144.

Adams, M.B., Hardwick, P. and Zou, H. (2008) 'Reinsurance and corporate taxation in the United Kingdom life insurance industry', Journal of Banking and Finance 32(1): 101-115.

Akotey, O.J., Osei, K.A. and Gemegah, A. (2011) 'The demand for micro insurance in Ghana', Journal of Risk Finance 12(3): 182-194. 
Angove, J. and Tande, N. (2011) A Business Case for Micro-Insurance: An Analysis of the Profitability of Micro-Insurance for Five Insurance Companies, Geneva, Switzerland: Micro-Insurance Innovation Facility, International Labor Organization.

Arellano, M. and Bond, S. (1991) 'Some tests of specification for panel data: Monte Carlo evidence and an application to employment equations', Review of Economic Studies 58(2): 277-297.

Arrow, J.K. (1963) 'Uncertainty and the welfare economics of medical care', American Economic Review 53(5): 941-973.

Baltagi, B.H. (2004) Panel Data: Theory and Applications, Heidelberg: Physica-Verlag.

Blundell, R. and Bond, S. (1998) 'Initial conditions and moment restrictions in dynamic panel data models', Journal of Econometrics 87(2): 115-143.

Bond, S.R. (2002) Dynamic panel data models: A guide to micro data methods and practice, Institute of Fiscal Studies, Cenmap working paper CWP09/02.

Cargill, T.F. and Troxell, T.E. (1979) 'Modelling life insurance savings: Some methodological issues', Journal of Risk and Insurance 46(4): 391-410.

Churchill, C. (2006) Protecting the Poor: A Microinsurance Compendium, Geneva, Switzerland: International Labor Organization.

Churchill, C. (2007) 'Insuring the low-income market: Challenges and solutions for commercial insurers', The Geneva Papers on Risk and Insurance - Issues and Practice 32(3): 401-412.

Churchill, C., Phillips, R.D. and Reinhard, D. (2011) 'Introduction to the 2011 symposium issue of JRI on microinsurance', Journal of Risk and Insurance 78(1): 1-5.

Cohen, M. and Sebstad, J. (2005) 'Reducing vulnerability: The demand for microinsurance', Journal of International Development 17(3): 397-474.

Cummins, J.D. (1991) 'Statistical and financial models of insurance pricing and the insurance firm', Journal of Risk and Insurance 58(2): 261-302.

Doherty, N.A. and Garven, J. (1995) 'Insurance cycles: Interest rates and the capacity constraint model', Journal of Business 68(3): 383-404.

Dror, D.M. and Armstrong, J. (2006) 'Do micro health insurance units need capital or reinsurance? A simulated exercise to examine different alternatives', The Geneva Papers on Risk and Insurance - Issues and Practice 31(4): 739-761.

Giesbart, L., Steiner, S. and Bendig, M. (2011) 'Participation in micro life insurance and the use of other financial services in Ghana', Journal of Risk and Insurance 78(1): 7-35.

He, E. and Sommer, D.W. (2010) 'Separation of ownership and control: Implications for board composition', Journal of Risk and Insurance 74(2): 265-295.

Hochrainer, S., Mechler, R. and Pflug, G. (2009) 'Climate change and financial adoption in Africa. Investigating the impact of climate change on the robustness of index-based microinsurance in Malawi', Mitigation and Adaption Strategies for Global Change 14(3): 231-250.

Jacobsen, G. (2009) 'Health and death risk and income decisions: Evidence from microfinance', Journal of Development Studies 45(6): 934-946.

Jensen, M. (1986) 'Agency costs of free cash flow, corporate finance and takeovers', American Economic Review: Papers and Proceedings 76(2): 323-339.

Jensen, M.C. and Meckling, W.H. (1976) 'Theory of the firm: Managerial behavior, agency costs and ownership structure', Journal of Financial Economics 3(3): 305-360.

Ligon, E., Thomas, J.P. and Worrall, T. (2002) 'Informal insurance arrangements with limited commitment: Theory and evidence from village economies', Review of Economic Studies 69(1): 209-244.

Lloyd's of London (2009) Insurance in Developing Countries: Exploring the Opportunities in Microinsurance, London, UK: Lloyd's Micro-Insurance Centre.

Mathewson, G.F. (1983) 'Information, search and price variability of individual life insurance contracts', Journal of Industrial Economics 32(4): 131-148.

Matul, M., McCord, M.J., Phily, P. and Harms, J. (2010) The Landscape of Microinsurance in Africa: Microinsurance Paper 4, Geneva, Switzerland: International Labor Organization.

Mayers, D. and Smith, C.W. (1981) 'Contractual provisions, organizational structure and conflict control in insurance markets', Journal of Business 54(3): 407-434. 
Mayers, D. and Smith, C.W. (1982) 'On the corporate demand for insurance', Journal of Business 55(2): 281-296.

Mayers, D. and Smith, C.W. (1988) 'Ownership structure across lines of property-casualty insurance', Journal of Law and Economics 31(2): 351-378.

Mayers, D. and Smith, C.W. (1990) 'On the corporate demand for insurance: Evidence from the reinsurance market', Journal of Business 63(1): 19-40.

Mayers, D. and Smith, C.W. (1994) 'Managerial discretion, regulation, and stock insurer ownership structure', Journal of Risk and Insurance 61(4): 638-655.

Mester, L.J. (1989) 'Testing for expense preference behavior: Mutual versus stock savings and loans', Rand Journal of Economics 20(4): 483-498.

Omar, O.E. (2007) 'The retailing of life insurance in Nigeria: An assessment of consumer attitudes', Journal of Retail Marketing Management Research 1(1): 41-47.

Osoka, O. (1992) Insurance and the Nigerian Economy, Lagos, Nigeria: Panache Publications.

Paal, B. and Wiseman, T. (2011) 'Group insurance and lending with endogenous social collateral', Journal of Development Economics 94(1): 30-40.

Purnanandam, A. (2008) 'Financial distress and corporate risk management: Theory and evidence', Journal of Financial Economics 87(3): 706-739.

Roth, J., McCord, M.J. and Liber, D. (2007) The Landscape of Microinsurance in the World's 100 Poorest Countries, Appleton, WI: Microinsurance Centre.

Rothschild, M.J. and Stiglitz, J. (1976) 'Equilibrium in competitive insurance markets: An essay on the economics of imperfect information', Quarterly Journal of Economics 90(4): 629-649.

Smith, M.L. (1989) 'Investment returns and yields to holders of insurance', Journal of Business 62(1): 81-98. Swiss Re (2010) Microinsurance-Risk Protection for 4 Billion People, Sigma No. 6, Zurich, Switzerland: Swiss Re.

World Bank (2010) African Development Indicators, Washington, DC: World Bank.

Yusuf, T.O., Gbadamosi, A. and Hamadu, D. (2009) 'Attitudes of Nigerians towards insurance services: An empirical study', African Journal of Accounting, Economics, Finance and Banking Research 4(4): 34-46.

\section{About the Author}

Olajumoke Olaosebikan is the Reinsurance Group of America (RGA) Doctoral Scholar at the School of Management, University of Bath. Her main research interests are focused on the areas of development finance and risk management in Sub-Sahara Africa. Her research project examines the Determinants of Micro-Life Insurers in Nigeria and the Republic of South Africa. She is also an Assistant Examiner in Finance on the external degree programme run by the London School of Economics and Political Science. 